\title{
Dialog Peradaban dan Falsafah Pendidikan Islam: Implimentasi dalam Kurikulum dan Kokurikulum Subjek Umum Fakulti Tamadun Islam, UTM
}

\author{
Aminudin Hehsan ${ }^{a^{*}}$, Zulkiflee Haronª, Mohd. Nasir Ripina, Yusuf Abdul Azeez ${ }^{b}$, Shahrel Ahmad Shuhel Ahmad \\ ${ }^{a}$ Fakulti Tamadun Islam, Universiti Teknologi Malaysia, 81310 UTM Johor Bahru, Johor, Malaysia \\ ${ }^{b}$ Fakulti Shariah, Universiti Sains Islam Malaysia, USIM, 71800 Nilai, Negeri Sembilan, Malaysia \\ 'Centre of Research for Figh Science and Technology (CFiRST), 81310 UTM Johor Bahru, Johor, Malaysia
}

*Corresponding author: ahehsan@utm.my

\begin{abstract}
Dialogue of civilizations is not a new term in the world of human civilization, but its application in human life begins simultaneously with human existence on this earth. It becomes one of the medium to apply the values of understanding and positive interaction between two way communications, sharing perspectives for solving problems in various aspects, tolerance, agreed cooperation, exchange opinions and ideas. As a result, it is able to bring to the circumstances where all parties can benefit or be identified as a win win situation. Besides, the Islamic education is the process of training and educating and molding the character and attitude of the human person. Aiming to foster the perfect personality in many aspects of life in physical, spiritual, mental, even moral social. It needs to be developed based on the values of Islamic and there needs to be alignment between the curriculums with the teachings of Islam itself. The result, then formed a curriculum that corresponds to human nature, corresponding to each age ratings and demands to give birth during the development of a brilliant public institutions. Thus, education and community issues are is implemented effectively, it can act as an agent to maintain and spread the culture according to the progress and development currency. In the context of public high school in teaching institutions the two elements that are very tightly linked and can't be separated and have the goal of the thorough and parallel to the global situation. If it as a reflection of Malaysian society, instead of them as heir to the country leaders and boosters advanced society. How would the situation prevailing polarization of the conflict and the silent various ethnic, tenuous relationship between religion and nation in the students who should be expected. One approach to dealing with conflict and polarization of people in the students, the Ministry of Higher Education, Malaysia has required students Public University (UA) and Private University (US) took the subject of Islamic Civilization and Asian Civilization, the State and the relationship ethnicity as a preparation towards society mutual respect between each other through the medium of education and dialogue between civilizations. One study analyzed the students' opinion about the teaching and learning of TITAS has been implemented in UTM. In addition, analyzing the results of the assessment based on the four elements TITAS, the group assignment (20\%), presentation (10\%), tests or quizzes (20\%) and e-learning or generic skills (10\%). The results are then analyzed using Statistical Package for Social Science (SPSS) version 20.0 for Windows. The results and findings have clarified the mean (average) which is in the very high or very positive (> 4.00 ) in the analysis of teaching and learning styles findings and analysis of the findings of the assessment TITAS four elements TITAS. In conclusion, the elements of civilization that has been incorporated into every element in the implementation of the subject TITAS plays a very important role in fostering a tolerant attitude among the races in Malaysia.
\end{abstract}

Keywords: Dialogue of civilizations; philosophy of Islamic education

\begin{abstract}
Abstrak
Dialog peradaban bukanlah istilah baru dalam dunia peradaban manusia, malahan aplikasinya dalam kehidupan manusia bermula serentak dengan kewujudan manusia di bumi ini. Ia menjadi satu wadah untuk menerapkan nilai-nilai persefahaman dan interaksi positif antara dua hala, berkongsi perspektif bagi menyelesaikan masalah dalam pelbagai aspek, bertoleran, kerjasama yang disepakati, bertukar-tukar pendapat dan buah fikiran. Natijahnya, mampu membawa kepada keadaaan semua pihak dapat mengambil manfaat atau dikenali dengan win-win situation. Pendidikan Islam pula sebagai proses melatih dan mendidik serta membentuk tabiat dan sikap seseorang manusia. Bertujuan membina keperibadian yang sempurna dalam berbagai aspek kehidupan samada jasmani, rohani, akal, akhlak mahupun sosial. Ia perlu dibangun berdasarkan nilai-nilai Islamiah dan perlu ada kesejajaran antara kurikulum dengan ajaran Islam itu sendiri. Hasilnya, maka terbentuklah kurikulum yang sesuai dengan fitrah manusia, bersesuaian dengan setiap peringkat umur dan tuntutan perkembangan semasa bagi melahirkan institusi masyarakat yang cemerlang. Oleh itu, pendidikan dan permasalahan masyarakat merupakan dua elemen yang sangat berkait rapat dan tidak dapat dipisahkan serta mempunyai matlamat yang menyeluruh dan sejajar dengan situasi sejagat. Jika dilaksanakan secara berkesan ia dapat bertindak sebagai sebuah agen untuk mengekal dan menyebarkan kebudayaan yang sesuai dengan kemajuan serta pembangunan semasa. Dalam konteks masyarakat pelajar di institusi pengajian tinggi sebagai cerminan masyarakat Malaysia, malah mereka sebagai pewaris pemimpin negara dan pemacu masyarakat maju. Bagaimana keadaannya jika berlaku polarisasi kaum, konflik senyap berbagai kaum dan etnik, hubungan yang renggang antara agama dan bangsa dalam kalangan pelajar yang selayaknya diharapkan. Salah satu pendekatan bagi menangani konflik dan polarisasi kaum dalam kalangan pelajar maka Kementerian Pendidikan Malaysia telah mewajibkan pelajar Universiti Awam (UA) mahupun Universiti Swasta (US) mengambil subjek Tamadun Islam dan Tamadun Asia, Kenegaraan dan Hubungan Etnik sebagai satu persiapan ke arah masyarakat yang saling hormat-menghormati antara satu sama lain melalui medium pendidikan dan dialog antara peradaban. Satu kajian menganalisis pendapat pelajar tentang gaya pengajaran dan pembelajaran subjek TITAS telah dilaksanakan di UTM. Selain itu, menganalisis hasil penilaian berdasarkan empat elemen TITAS, iaitu tugasan kumpulan (20\%), pembentangan (10\%), ujian atau kuiz (20\%) dan e-learning atau kemahiran generik (10\%). Dapatan kemudiannya dianalisis menggunakan perisian Statistical Package for Social Science (SPSS) versi 20.0 untuk Windows. Hasil kajian dan dapatan telah menjelaskan nilai min (purata) yang berada dalam tahap sangat tinggi atau sangat positif $(>4.00)$ di peringkat analisis dapatan gaya pengajaran dan pembelajaran TITAS dan analisis dapatan penilaian empat elemen TITAS. Kesimpulannya, elemen dialog peradaban yang telah diserapkan dalam setiap elemen dalam pelaksanaan subjek TITAS memainkan peranan yang sangat penting dalam memupuk sikap bertoleransi di antara kaum di Malaysia ini.
\end{abstract}

Kata kunci : Dialog peradaban; falsafah pendidikan Islam

(C) 2016 Penerbit UTM Press. All rights reserved 


\subsection{PENGENALAN}

Menelusuri sejarah ketamadunan manusia yang saling berinteraksi dapat diperhatikan bahawa wujud hubungan baik yang terjalin dalam kepelbagaian tamadun. Perkongsian nilai ini menjadi suatu pengalaman yang selayaknya terus dipertahankan oleh setiap generasi. Pengalaman praktikal dalam kehidupan dapat menghasilkan momentum dan daya kekuatan yang harus dikembangkan bagi kehidupan generasi muda masa kini dan akan datang. Bagi menyuburkan pengalaman yang sedia ada seharusnya direalisasikan melalui dialog ketamadun atau dialog peradaban. Kita akur dan menerima bahawa terdapat perbezaan-perbezaan seperti perbezaan ideologi dan agama, budaya dan cara hidup namun tidak bermakna kita tidak boleh berbincang dan berdiolog dalam perkara-perkara berkaitan kehidupan yang berasaskan kepada hal-hal yang disepakati bersama. Usaha melakukan perubahan terhadap perkara-perkara yang disepakati memerlukan sikap dan sifat lapang dada dan terbuka sekaligus sifat sayang-menyayangi.

Isu mengenai pengamalan dan perlaksanaan dialog peradaban merupakan topik yang penting dalam usaha mengembalikan keharmonian dan ketenteraman sesebuah masyarakat dan negara. Perpecahan dan konflik yang berlaku dalam masyarakat dunia pada amnya terjadi adalah disebabkan oleh pelbagai sebab. Mungkin barangkali dari sebab integriti sahsiah individu hinggalah kepada integriti pemimpin dalam sesebuah masyarakat, dan melibatkan pelbagai sektor daripada sektor ekonomi, politik, sosial, agama dan sains dan teknologi. Hakikatnya masyarakat dunia tidak dapat mengelak daripada perbezaan-perbezaan yang bersifat biologikal, demografi, geografi, autoriti kekuasaan dan kepelbagaian individu dalam masyarakat, namun keadaan ini harus ditangani dan diurus dengan baik. Sebab itu salah satu cara untuk mengurangkan jurang salah faham dan kesefahaman, maka dialog antara peradaban diketengahkan sebagai salah satu perantara yang dikatakan berkesan.

\subsection{DEFINISI DIALOG}

Menurut (Kamus Dewan 2005), dialog bermaksud perbincangan atau perundingan antara dua pihak yang bertelingkah kepentingannya. Selain itu berdialog yang disebutkan dalam Kamus Dewan juga memberi erti bertukar-tukar pendapat atau pandangan mengenai sesuatu isu secara terbuka. Menurut (Basri, 1990), dialog adalah suatu bicara, komunikasi antara dua pihak atau lebih samada secara formal atau tidak formal. Selain itu, dialog bukannya semata-mata satu siri perbicaraan malahan ia adalah satu cara berfikir yang baru; satu cara untuk melihat alam dan kehidupan serta maknanya. Dialog dalam bahasa Arab ialah hiwar. Dari segi etimologi, kata dasar hiwar merujuk kepada penekanan konsep asas di dalam tamadun serta budaya Islam. Di dalam Lisanul Arab Ibn Manzur (1955-1956), Al-Hiwwar atau dialog bermakna kembali, "mereka berdialog" bermakna mereka mengambil dan memberi di dalam perbualan. At-Tahawwur pula adalah perbuatan mengambil bahagian dalam dialog menunjukkan kepada sambutan atau kemampuan untuk menjawab, Al-Haur pula adalah melangkah keluar dari sesuatu atau kembali kepadanya. Al-Muhawara merujuk kepada logik dan retorik dalam dialog. Menurut (Muzaffar, 2003) pula, dialog peradaban bermaksud inter-komunikasi dan persefahaman antara tamadun berdasarkan kepada elemen penting iaitu memahami budaya masing-masing tanpa ada rasa prejudis terhadap masyarakat daripada kaum yang lain.

Oleh yang demikian, dialog peradaban dapat difahami sebagai perundingan, interaksi positif antara dua pihak, komunikasi dua hala atau lebih peradaban yang bertujuan untuk memupuk persefahaman dan pengertian, berkongsi perspektif dalam menyelesaikan masalah dalam pelbagai aspek, bertoleran sesama rakan dialog yang berlainan peradaban, kerjasama yang disepakati, bertukar-tukar pendapat dan fikiran dan sebagainya. Istilah dialog peradaban merupakan satu istilah yang boleh membawa banyak pengertian dan konotasi bergantung dimensi mana yang hendak kita bahaskan. Dua perkataan iaitu dialog dan peradaban bukanlah istilah baru dalam dunia peradaban manusia. Malah perkataan tersebut merupakan perkataan yang lama dari segi aplikasinya dalam kehidupan manusia sejak wujudnya manusia di bumi ini.

Menurut Fadil (2003) dalam bukunya Perspektif Qur'ani: Siri Wacana Tematik menjelaskan dialog sebagai satu pendekatan dakwah Qur'ani. Beliau menghuraikan satu perspektif dakwah bahawa Quran menggunakan istilah jidal (dialog) yang membawa dua pengertian iaitu positif dan negatif. Dalam bentuk negatif jidal bermaksud perbuatan sengaja mempertikai kebenaran dengan alasan-alasan yang diada-adakan seperti dilakukan oleh orang-orang kafir, seperti terdapat dalam surah al-Anfal: 6, surah al-Hajj: 8. Manakala yang positif pula ianya diertikan sebagai al-Hiwar al-Hadi “ dialog yang tenang”. Dialog yang tenang ialah mencari dan membuktikan kebenaran seperti termaktub dalam surah al-Mujadalah:1. Menurut beliau, pengertian yang positif dan sihat yang dianjurkan oleh Quran adalah seperti yang terdapat dalam surah al-Ankabut: 48 dan surah al-Nahl:125. Istilah jidal digunakan dalam surah al-Nahl: 125 , bahawa jidal terikat dengan cara yang lebih baik dapat difahami sebagai dialog yang tidak mengandungi penghinaan, celaan, atau unsur-unsur lain yang boleh menimbulkan prasangka buruk terhadap $d a{ }^{\prime} i$ (penyampai mesej Islam). Tambah beliau lagi, bahawa dialog yang sihat dapat memberikan kesan kerana matlamatnya bukan untuk menang, tetapi untuk menyakinkan tentang kebenaran walau kenyataannya manusia sukar mengubah fikiran dan pendirian jika mereka berasa direndahkan, diremehkan atau dikalahkan. Kerelaan untuk mengubah pandangan hanya mungkin berlaku apabila dapat diyakinkan tanpa berasa kehilangan harga diri.

Dialog tidak sama dengan debat ataupun diskusi. Dari aspek etimologi, diskusi lebih kepada kegiatan dengan tujuan memecahkan sesuatu masalah. Sedangkan debat ialah kegiatan yang bermakna lebih kepada mengalahkan pendapat orang lain. Diskusi membawa pertukaran nilai dan lebih bermakna, tetapi kadang kala ianya masih dipergunakan untuk membawa objek bagi memenangkan fakta-fakta tertentu,masih mengandungi makna ada proses yang menang dan kalah. Sedangkan dialog mengandungi makna yang lebih luas dan membawa kepada keadaaan semua pihak dapat mengambil manfaat atau dikenali win-win situation. Dengan berkembangnya pendidikan massa, komunikasi dan perjalanan yang semakin mudah ditempuh, peningkatan ekonomi dunia, cabaran globalisasi, pemanasan global telah meningkatkan semangat di kalangan masyarakat dunia untuk melaksanakan dialog dan memandangnya sebagai suatu keperluan agar pertukaran pendapat dapat kongsi bersama. Dengan berkembangnya khazanah budaya dan peradaban menyebabkan dialog semakin relevan. Oleh itu, zaman ini adalah zaman dialog seperti yang nyatakan oleh Swidler dalam kata pengantar buku Muslim in Dialogue, katanya 'this series of volumes on religions and ideologies, in dialogue is concerned: to help move us out of the age of monologue into the Age of Dialogue".

Dalam ertikata lain dialog peradaban memerlukan satu sikap ingin tahu dan belajar apa yang ada di luar lingkungan kita. Seperti pandangan pemikir sosiologi Indonesia, Kuntowijoyo menyatakan bahawa dialog peradaban dan agama-agama sebenarnya satu konsep 
baru hubungan antara umat beragama daripada pelbagai peradaban yang bersifat 'ke luar' dan tidak asyik dengan diri sendiri sahaja; melihat ke depan dengan bersama-sama menghadapi masa depan kemanusiaan (Sulaiman, 2004).

\subsection{MATLAMAT DAN TUJUAN DIALOG PERADABAN}

Dialog peradaban dalam konteks yang luas adalah bertujuan untuk membincangkan antara dua atau lebih pihak bagi mencari jalan penyelesaian yang kreatif dan baru dalam menangani kemelut dan masalah yang dihadapi oleh umat manusia. Dalam konteks Islam, kejadian manusia yang berbagai perbezaan dari segi geografi, demografi, biologi dan budaya adalah satu anugerah Allah SWT supaya manusia kenal mengenali antara satu sama yang lain. sekarang. Quran menjelaskan tujuan penciptaan manusia dari berbagai etnik, kaum, bangsa sebagaimana termaktub dalam maksud Firman Allah SWT;

"Wahai umat manusia, sesungguhnya Kami telah menciptakan kamu dari lelaki dan perempuan (Adam dan Hawa) dan Kami telah menjadikan kamu berbangsa-bangsa dan berpuak-puak supaya kamu berkenal-kenalan (dan beramah mesra di antara satu dengan yang lain). Sesungguhnya Allah Maha Mengetahui Lagi Maha Mendalam Pengetahuan-Nya."

(al-Hujurat :13)

Menurut Fadil (2003) dalam mengambil pendapat Prof Osman Bakar, penegasan ayat Quran di atas adalah tujuan utama dialog peradaban iaitu untuk membawa komuniti-komuniti dari berbagai latar belakang bersama untuk berinteraksi dan mengenali antara mereka untuk mencari kebaikan bersama kerana dipaksa oleh keadaan untuk hidup bersama walaupun mempunyai kepercayaan agama, cara kehidupan beragama dan ideologi politik yang berbeza. Yusuf Al-Qaradhawi berpendapat bahawa sememang Allah SWT menjadikan dan mencipta langit, bumi, berlainan bahasa dan warna kulit seperti yang di sebut dalam surah al-Rum ayat 22, adalah anugerah Allah SWT, begitu juga Allah SWT mencipta manusia berjenis-jenis dan berlainan antara satu dengan yang lain seperti dalam surah Hud ayat 118-119, sebagai satu ketentuan Allah. Jadi dengan variasi perbezaan dikalangan manusia adalah untuk manusia berinteraki, bergaul dan bekerjasama atas prinsip kebajikan dan taqwa. Beliau menyeru membuka dialog agar saling memahami dialog yang bertujuan mendekatkan dan bersefahaman di antara manusia tetapi tidak menggugurkan kewajiban menyeru kepada aqidah dan risalah Islam.

Konsep kenal mengenali (al-Ta'aruf) yang dianjurkan oleh Islam adalah melalui interaksi dan komunikasi antara dua pihak atau lebih. Salah satu natijah penting dari aplikasi konsep ta'aruf akan membawa secara signifikan pada dialog ialah ta'awun (kerjasama atau tolong-menolong). Kerjasama antara manusia boleh berlansung dalam pelbagai aspek dan isu. Isu-isu semasa seperti kemiskinan, kesihatan, kepadatan populasi, ekologi, maslah sosial dapat digembeleng bersama dalam membangunkan sesebuah masyarakat. Dr. Abdul Aziz Othman al-Twaijri menggariskan beberapa objektif dialog iaitu:

(a) Saling menghormati dalam perspektif Islam merupakan wadah asas dalam dialog sebagaimana penyataan al-Quran yang bermaksud:

(b) "Dan janganlah kamu cerca benda-benda yang mereka sembah yang lain dari Allah, kerana mereka kelak, akan mencerca Allah secara melampaui batas dengan ketiadaan pengetahuan." (al-An'am: 108)

(c) Persamaan dan keadilan menurut perspektif Islam adalah tapak asas memungkinkan berlakunya perbincangan antara dua atau lebih pihak demi mencapai persetujuan bersama. Tiada pihak yang direndahkan atau diremehkan dan mendapat perhatian secara saksama dan adil di semua tahap dan peringkat,

(d) Menolak sikap fanatik dan perkauman. Minda yang terbuka dan luas dan mengamalkan sifat sederhana dalam semua perkara dapat menjamin penolakan terhadap sikap fanatik dan perkauman.

Berdasarkan pandangan-pandangan yang diutarakan di atas, dapat kita simpulkan bahawa dialog peradaban adalah amat perlu dalam konteks masyarakat majmuk atau pelbagai tamadun. Fahaman dalam kalangan peserta dialog dan mereka yang serius dalam dialog perlu mendalami konsep, tujuan, kaedah berdialog dan prasarana dialog. Pastinya peserta dialog atau pencinta dialog perlu ada persediaan emosi, minda dan rohani bagi mempastikan kejayaan dialog dan natijah yang manfaat bersama. Maka berbekalkan persediaan dan persiapan diharapkan agar dialog peradaban menjadi satu wadah untuk menerapkan nilai-nilai persefahaman dan interaksi antara peradaban. Natijah seterusnya mampu menghasilkan kerjasama antara satu sama lain.

\subsection{DIALOG PERADABAN DI MALAYSIA}

Usaha-usaha dialog di Malaysia mulai dirasakan dengan adanya institusi tertentu. Malah usaha-usaha mempromosi dialog peradaban dilakukan oleh beberapa ahli-ahli akademik dan juga sokongan kuat daripada pihak kerajaan. Institusi yang berperanan penting ialah Pusat Dialog Peradaban yang ditubuhkan di Universiti Malaya pada tahun 1996. Ada beberapa faktor yang memangkinkan kewujudan institusi ini antaranya sifat kelbagaian budaya yang berpotensi kepada perbezaan hubungan dan tekanan antara budaya. Faktor yang lain ialah adanya isu semasa seperti kebangkitan nilai-nilai dan Budaya Asia ke atas barat, arus globalisasi, keperluan keatas dialog bagi perdamaian. Faktor-faktor kemanusiaan yang juga berperanan dalam pembentukan pusat dialog peradaban ini ialah ketidakfahaman antara etnik, adanya peningkatan jurang pemisah diantara yang kaya dan yang miskin, tidak terdedahnya masyarakat keatas kemajuan teknologi dan sains. Adanya krisis lingkungan, kerosakan nilai dalam rumah tangga dan sebagainya. Beberapa peristiwa yang telah dijalankan yang melibatkan program-program diperingkat antarabangsa dan kebangsaan. Isu-isu dialog yang dibicara merangkumi bidang yang luas (Khir, 2005). 


\subsection{PENDIDIKAN ISLAM: KONSEP, FALSAFAH SERTA MATLAMATNYA}

Menurut ilmu Tatabahasa Melayu "Pendidikan" merupakan kata terbitan yang berasal dari kata dasar "didik" yang membawa erti jaga, pelihara atau ajar dengan hati-hati sejak kecil. menurut (Iskandar, 2000), dalam bahasa Inggeris, pendidikan dikenali sebagai "education" berasal daripada bahasa Latin yang merupakan cantuman dua patah perkataan iaitu "e'ex" beerti keluar dan "ducereduc" bererti “memimpin” Shipley (1957). Menurut Dr. 'Abdulah bin Ishak, dua perkataan ini dapat diinterpretasikan sebagai proses menyerapkan ilmu pengetahuan ke dalam bentuk teori serta melakukan latihan dalam bentuk praktis bagi membentuk pribadi dan watak serta mencungkil bakat (A. A. Ishak, 1995). Dalam bahasa Arab terdapat beberapa istilah yang biasa digunakan dalam pengertian pendidikan iaitu taclim, tarbiyyah dan ta'dib. Walaupun ketiga-tiga perkatan tersebut memberikan pengertian yang sama bagi mendefinisikan perkataan pendidikan tetapi perkataan tarbiyyah lebih menonjol dan meluas penggunaannya di seluruh tanah Arab juga di negara umat Islam. Penonjolan penggunaan perkataan tarbiyyah mungkin kerana ia dilihat dari segi pengertiannya yang umum. Kalimah ini secara realitinya mencakupi pengertian pendidikan yang bukan sahaja ditujukan kepada manusia bahkan kepada makhluk Allah SWT yang lain yang membawa erti mendidik, mengajar, memelihara dan menternak.

Arifin (1991) menjelaskan secara umum, pendidikan dapat dilihat sebagai proses usaha manusia untuk membina keperibadiannya sesuai dengan nilai-nilai yang terdapat di dalam masyarakat dan kebudayaannya menurut (Brubacher, 1969). Sehubungan dengan ini, dapat dipastikan bahawa proses pendidikan berlaku sepanjang peradaban umat manusia. Dalam ertikata lain, pendidikan pada hakikatnya merupakan usaha manusia untuk menyempurnakan hidupnya (Zuhairini, 1992). Menurut John Dewey dan Lodge, pendidikan dengan kehidupan manusia adalah suatu proses yang berjalan seiringan dan tidak terpisah di antara satu dengan lain (Dewey, 1966). Oleh yang demikian ini, dapat difahami bahawa pendidikan amat memerlukan penelitian dan kajian samada dalam bentuk konsep atau operasinya sehingga dicapai relevansi dan kemampuan untuk menjawab segala tentangan dan menangani segala permasalahan yang dihadapi oleh umat manusia. Jika dilihat dari segi pemindahan nilai-nilai, sistem pendidikan mempunyai dua fungsi yang besar (Muhammady, 1991);

(a) Berfungsi untuk menjaga sistem yang sedia ada dengan mengambil perhitungan kepada nilai-nilai baru dalam arus perkembangaannya atau melahirkan satu kelompok masyarakat baru.

(b) Berfungsi sebagai jentera pembaharuan (medernization) kepada masyarakat.

Pendidikan juga bertujuan untuk menyebarkan pengalaman dan kebudayaan manusia daripada satu generasi kepada satu generasi. Dalam pendidikan Islam penyebaran pengalaman ini boleh dibahagikan kepada dua kategori iaitu (Kasa, 1994);

(a) Pengalaman dalam bentuk kemahiran serta pengetahuan teknikal yang keadaannya sentiasa berubah dari semasa ke semasa.

(b) Pengalaman berasaskan nilai-nilai tetap yang terdapat dalam agama. Pengalaman ini tidak berubah dan boleh didapati daripada al-Quran dan al-Sunnah.

Ahli-ahli pendidikan Islam menyakini bahawa pendidikan yang realiti dan ideal adalah bersumberkan dari al-Quran dan al-Sunnah. Justeru, definisi pendidikan Islam itu sendiri, mengandungi erti dan kaitan yang rapat dengan roh al-Quran dan perjalanan hidup Rasulullah s.a.w. Sehubungan ini, (Jamali, 1972), (Shaibani, 1975), (Ahmad, 1979 ), dan (Langgulung, 1979) mendefinisikan pendidikan sebagai proses melatih dan mendidik serta membentuk tabiat dan sikap seseorang manusia ke arah membina keperibadian yang sempurna dalam berbagai aspek kehidupan samada jasmani, rohani, akal, akhlak mahupun sosial. Ia berdasarkan nilai-nilai Islamiah yang bersumberkan alQuran dan al-Sunnah bagi melahirkan manusia yang sempurna, beriman dan bertaqwa untuk mengabdikan diri kepada Allah SWT. Maka bertitik tolak dari pengertian ini, dapat dibuat kesimpulan bahawa pendidikan Islam itu adalah penekanan kepada konsep-konsep berikut;

(a) Pendidikan yang berterusan.

(b) Pembangunan seluruh potensi manusia (roh, akal dan jasad).

(c) Melaksanakan dua tuntutan;

(i) Sebagai hamba Allah SWT

(ii) Sebagai khalifah Allah SWT (vicegerent of Allah)

(a) Memakmurkan seluruh alam di atas dasar (Nahlawi, 1979);

(i) Kesepaduan dan kesempurnaan iman (faith)

(ii) Ilmu (knowledge) dan amal saleh (virtuous deed) untuk mencapai kebahagiaan hidup di dunia dan akhirat.

Menerusi penghayatan dari definisi pendidikan, dapat dipastikan bahawa setiap sistem pendidikan mempunyai matlamat untuk direalisasikan. Sistem pendidikan bukan Islam jelas mempunyai matlamatnya sendiri iaitu untuk melahirkan warganegara yang baik iaitu Kriteria yang menentukan warganegara yang baik itu akan mewujudkan perbezaan berdasarkan kepada sempadan negara, kebudayaan dan sejarah sesuatu bangsa yang berbeza di antara satu dengan yang lain. Hal ini berbeza dengan Islam yang tidak meletakkan matlamat pendidikan manusia itu hanya untuk negara sahaja tetapi manusia untuk Allah. Oleh sebab itu, pendidikan Islam mempunyai matlamat untuk melahirkan insan yang baik dan sempurna (insan saleh dan kamil) yang mencakupi kualiti-kualiti kemanusian sebenar (Muhammady, 1991).

Imam al-Ghazali (1939) telah menyatakan bahawa matlamat pendidikan ialah untuk mendekatkan diri kepada Allah SWT bukan kerana pangkat dan bermegah-megah, mencari harta dan menipu. Menurut (Mohammad Hamid al Efendi), matlamat pendidikan Islam ialah untuk melahirkan individu yang baik dalam kehidupan masyarakat di samping berbakti kepada Allah SWT bagi mendapatkan kebahagiaan di akhirat. Begitu juga bagi Ishak Farhan (1979) yang berpendapat bahawa tujuan pendidikan itu adalah untuk mendidik individu supaya menjadi insan yang baik dan bertaqwa, berfungsi sebagai warganegara yang berguna dan pencetus kepada membawa rahmat Allah SWT kepada manusia.

Melalui keyataan yang diberikan, jelas menunjukan bahawa pendidikan Islam meletakkan matlamatnya kepada kesempurnaan kemanusiaan yang sebenar, mengatasi batas-batas sempadan negara, keturunan dan kebudayaan sesuatu bangsa. Ini adalah kerana Islam sentiasa meletakkan ketinggian manusia mengikut hubungan hatinya dengan tuhan Yang Maha Esa. Pendidikan Islam juga bertujuan membina dan melatih diri dengan disiplin-disiplin yang bersumberkan al-Quran dan al-Sunnah yang sentiasa memberikan rangsangan dan bahan serta panduan untuk peningkatan akal, jasad dan roh. Sebaliknya bahan-bahan yang disediakan dalam pendidikan lain adalah untuk 
peningkatan akal dan fizikal manusia semata-mata. Hasan Langgulung menegaskan, matlamat pendidikan menjalankan fungsi yang semuanya bersifat normatif (Langgulung, 1986);

(a) Menentukan haluan bagi proses pendidikan iaitu halatuju dalam usaha mendidik atau perubahan yang dihasilkan melalui pendidikan.

(b) Merangsang dan mendorong supaya bekerja dengan penuh kesungguhan bagi mencapai nilai-nilai murni dalam kehidupan.

(c) Menjadi kriteria dalam menilai proses pendidikan dengan menilai pencapaian pendidikan itu samada berjaya atau sebaliknya.

Matlamat adalah sebagai alat untuk menentukan haluan pendidikan dapat dilihat melalui tiga peringkat iaitu tujuan khas, tujuan am dan tujuan akhir. Apabila digunakan dalam kurikulum, ketiga-tiga peringkat ini mencakupi aspek tertentu pada matlamat tersebut (Langgulung, 1986).

Perkataan falsafah pula merupakan suatu sebutan yang telahpun menjadi sebatian dalam perbendaharaaan kata bahasa dan merupakan asimilasi bagi mengembang dan mengukuhkan bahasa Melayu di rantau ini. Ia seringkali juga dikombinasikan dengan pendidikan di samping penjenisan ilmu pengetahuan yang lain (A. A. b. Ishak, 1989). Menurut sejarah perkembangan bahasa, perkataan falsafah berasal dari bahasa Yunani iaitu Philes Sophic. Philes bererti cinta, kaji atau hargai dan Sophic beerti hikmah, kebijaksanaan atau kebenaran. (Zuhairini, 1992) menyatakan dari rangkaikata bahasa Yunani ini akhirnya dipindahkan ke dalam bahasa Inggeris dengan sebutan Philosophy manakala dalam bahasa Malaysia pula disebut sebagai Falsafah. (Daia, 1974) menyatakan sebelum perkataan ini menyerap masuk ke dunia Islam, istilah al Hikmah dan al Hakim mempunyai pengertian dasar yang sama dengan falsafah (Raziq, 1959).

Menurut al-Shaibani (1975) dan Sadiq (1962), falsafah pendidikan merupakan suatu aktiviti yang diusahakan oleh ahli-ahli falsafah pendidikan untuk membuat penjelasan, penyusunan, penilaian dan mengubahsuai operasi pendidikan dalam usaha melaksanakan teori dan metode yang berhubung dengan pengalaman manusia. Justeru itu bolehlah diandaikan bahawa falsafah pendidikan merupakan asas penentuan konsep pelajaran dan pembelajaran samada berbentuk umum atau khusus, membentuk kurikulum, metode atau kaedah pembelajaran, objektif serta penilaiannya. Menurut H.M. Arifin (1991), terdapat tiga disiplin ilmu yang dapat membantu dalam usaha menyelesaikan permasalahan pendidikan iaitu;

(a) Etika atau teori tentang nilai.

(b) Epistimologi atau teori ilmu pengetahuan.

(c) Metafizik atau teori tentang realiti dan kenyataan atau disebalik kenyataan.

Oleh kerana falsafah pendidikan mempunyai ruang lingkup pemikiran mendalam tentang permasalahan fundamental manusia yang dihubungkan dengan tiga disiplin ilmu di atas, maka W.H. Kilpatrik menjelaskan terdapat tiga tugas asas falsafah pendidikan iaitu (Kilpatrick, 1961);

(a) Memberikan kritikan terhadap asumsi yang dipegang oleh pendidik.

(b) Membantu menjelaskan tujuan-tujuan pendidikan.

(c) Melakukan evaluasi secara mendalam tentang berbagai metode pendidikan yang digunakan untuk mencapai tujuan-tujuan pendidikan yang dipilih.

Sehubungan dengan ini, dapat dibuat kesimpulan bahawa falsafah Pendidikan Islam bertugas dalam tiga dimensi iaitu;

(a) Memberikan landasan dan sekaligus mengarahkan kepada proses perlaksanaan pendidikan berdasarkan ajaran Islam.

(b) Melakukan kritikan dan pembetulan terhadap proses perlaksanaan tersebut.

(c) Melakukan evaluasi terhadap metode dari proses pendidikan tersebut.

Ketiga-tiga fungsi tersebut berjalan di atas landasan cara berfikir yang bersifat sistematik, rasional, universal, radikal dan sepadu. Falsafah pendidikan mempunyai peranan yang begitu penting dalam sistem pendidikan lebih-lebih lagi untuk melakukan reformasi, kemajuan dan membina asas-asas yang kukuh. Di antara peranan yang dapat disumbangkan oleh falsafah dalam pendidikan ialah membentuk fikiran yang sempurna sesuai dengan nature operasi, motif dan peranan pendidikan. Meningkatkan lagi kemampuan bagi mengatasi masalahmasalah dan polisi pendidikan, membantu tahap perlaksanaan, metode dan sistem pembelajaran di samping menggariskan polisi dan teknik yang sistematik dan berkesan bagi kegunaan pengurusan dan pentadbiran di pusat-pusat pengajian (Abbud, 1990).

Dapat disimpulkan bahawa falsafah pendidikan Islam yang dikehendaki adalah suatu pemikiran mendalam, sitematik, logik dan menyeluruh yang terbentuk atau tersusun ke dalam suatu bentuk pemikiran atau konsepsi sebagai suatu sistem. Apabila dikaitkan dengan Islam, maka jelaslah falsafah tersebut merupakan penghasilan (menifestasi) dari pelbagai sumber daya fikiran, perasaan dan kemahuan berdasarkan ajaran Islam yang dinyatakan oleh ahli falsafah yang bernafaskan Islam di sepanjang masa dan tempat. Ruang lingkup pemikirannya juga tidak terbatas dalam lingkungan institusi Islam sahaja atau ilmu pengetahuan dan pengalaman keislaman semata-mata, bahkan menjangkau segala ilmu dan pengalaman yang luas seluas aspirasi masyarakat Muslim. Maka, pandangan dasar yang menjadi titik tolak perbincangannya adalah ilmu pengetahuan yang berbentuk teori dan praktikal dalam segala bidang keilmuan berkaitan dengan masalah pendidikan yang telah dan akan wujud dalam masyarakat yang berkembang terus tanpa sempadan.

\subsection{KONSEP KURIKULUM DAN KOKURIKULUM MENURUT FALSAFAH PENDIDIKAN ISLAM DALAM PEMBINAAN INSTITUSI-INSTITUSI PENGAJIAN}

Perkataan "kurikulum" berasal dari Bahasa Latin dan telah dipindahkan ke dalam Bahasa Inggeris disebut sebagai "curriculum" yang membawa maksud "a little racecource" iaitu suatu jarak yang harus ditempoh dalam pertandingan olahraga, kemudian telah dipindahkan ke dalam pengertian pendidikan menjadi "course of study or training" dan "circle of instruction" bermaksud suatu lingkaran pengajaran yang melibatkan guru dan murid. Kurikulum atau rancangan pelajaran dalam Bahasa Arab disebut sebagai "Manhaj" atau "Minhaj" yang merupakan kata terbitan dari kata dasar "Nahaja” bererti mengikut jalan atau suatu jalan. Perkataan kurikulum akhirnya digunakan untuk menerangkan tentang segala mata pelajaran yang dipelajari dan juga semua pengalaman yang harus diperolehi serta semua kegiatan yang harus dilakukan oleh anak didik (Horne, 1962 ). 
Menerusi pendekatan bahasa di atas, kurikulum dapat dilihat sebagai suatu program pendidikan yang dirancang dan dilaksanakan ke arah mencapai matlamat dan tujuan pendidikan (Daradjat, 1992). Terdapat perbezaan di antara maksud kurikulum dan kokurikulum sepertimana yang tercatat di dalam Kamus Dewan iaitu kurikulum bererti skop dan kandungan isi sesuatu mata pelajaran atau senarai kesemua mata pelajaran (kursus pengajian) di sekolah dan sebagainya (Iskandar, 2000). Manakala kokurikulum diertikan sebagai kegiatan atau aktiviti selain mata pelajaran yang diajarkan dalam bilik darjah tetapi dianggap sebagai sebahagian daripada kursus pendidikan di sekolah. Menurut Herman H. Horne dan Abd al Rahman Md. Aroff, di antara perkara yang dapat membantu untuk menghasilkan kurikulum yang mantap ialah (Horne, 1962 );

(a) Menilai tahap kemampuan dan keperluan yang diperlukan oleh anak didik (The ability and needs of children). Hal ini dapat dihasilkan melalui ilmu psikologi.

(b) Tuntutan yang sah dari masyarakat (The legitimate demands of society). Hal ini dapat dihasilkan melalui ilmu sosiologi.

(c) Keadaan alam semesta di mana kita hidup (The kind of universe in which we live). Hal ini dapat dihasilkan melalui ilmu falsafah.

Di antara tugas asas falsafah pendidikan Islam adalah menentukan arah atau halatuju ke arah merealisasikan matlamat pendidikan Islam itu sendiri yang disusun dan diprogramkan dalam kurikulumnya. Antara matlamat dan program, mestilah ada kesesuaian dan kesinambungan. Matlamat yang hendak dicapai mestilah tergambar di dalam program yang terbentuk di dalam kurikulum. Seterusnya akan mencerminkan arah dan tujuan yang dikehendaki dalam pendidikan. Arifin (1991) menyatakan kurikulum sesebuah institusi pendidikan mengandungi tiga komponen iaitu; tujuan, isi dan organisasi strategi. Tujuan kurikulum yang terdapat di sesebuah institusi pengajian itu dapat diklasifikasikan kepada dua kategori;

(a) Tujuan yang ingin dicapai oleh institusi secara keseluruhannya.

(b) Tujuan yang ingin dicapai dalam setiap bidang pelajaran.

Manakala isi program kurikulum diaplikasikan dalam dua bentuk;

(a) Jenis-jenis bidang pengajian yang ditawarkan.

(b) Isi program setiap bidang pengajian.

Organisasi adalah merupakan struktur (susunan) program suatu kurikulum yang dikenali sebagai "struktur horizontal" dan "struktur vertikal",

(a) Struktur horizontal adalah suatu kurikulum yang disusun bersesuaian dengan sesuatu program samada dalam bentuk ;

(b) Mata pelajaran secara terpisah (separate subject) atau

(i) Kelompok-kelompok mata pelajaran sesuai dengan bidang pengajian (broadfields) atau

(ii) Kesatuan program tanpa melihat kepada mata pelajaran atau bidang pengajian (integrated program)

(a) Struktur vertikal adalah suatu kurikulum yang disusun bersesuaian dengan perlaksanaan program samada dalam bentuk ;

(i) Sistem kelas yang peringkat kenaikannya dilakukan setiap tahun secara serentak, atau

(ii) Sistem tanpa kelas yang melibatkan kenaikan dari satu progran ke satu program, seterusnya dapat dilakukan pada setiap waktu tanpa perlu menuggu pelajar-pelajar yang lain, atau

(iii) Kombinasi di antara sistem kelas dengan sistem tanpa kelas.

Selanjutnya, dalam struktur program ini mencakupi sistem unit waktu yang digunakan, penjadualan dan pembahagian waktu setiap bidang pengajian dan lain-lain lagi. Strategi perlaksanaan suatu kurikulum pula, tergambar dari cara yang dilalui dalam melaksanakan pengajaran, menentukan penilaian, melaksanakan bimbingan dan cara di dalam mengatur kegiatan sekolah secara keseluruhan.

Kecemerlangan pencapaian dalam bidang ilmu pengetahuan dan pendidikan adalah merupakan kayu ukur untuk menentukan sejauhmana kejayaan sesebuah tamadun dan kemampuannya untuk bertahan. Kecemerlangan ini akan diperolehi sekiranya didasari dengan kurikulum pelajaran yang seimbang, bersepadu (integrated), terancang dan komprehensif. Sebagai langkah untuk merealisasikan matlamat ini, amat perlu kepada pembinaaan dan penyusunan kurikulum pelajaran yang mencerminkan falsafah, kebudayaan dan matlamat yang hendak dituju samada dari aspek sosial, politik dan ekonomi. Ia juga perlu bersifat fleksibel; iaitu merupakan suatu proses yang berterusan, berkembang, dinamik dan tidak statik, sejajar mengikut kehendak masyarakat yang sering terdedah dengan berbagai perubahan. (Nocholls, 1972) menjelaskan ini adalah kerana pendidikan dan permasalahan masyarakat merupakan dua elemen yang sangat berkait rapat dan tidak dapat dipisahkan.

Pendidikan mempunyai matlamat yang menyeluruh dan sejajar dengan situasi sejagat. Matlamat utama pendidikan secara umum sepertimana yang telah dinyatakan ialah menyediakan seseorang individu bagi memainkan peranan yang positif dalam semua aspek yang matlamat akhirnya untuk masyarakat. Bagi membangunkan daya usaha itu, pendidikan secara berkesan dapat bertindak sebagai sebuah agen untuk mengekal dan menyebarkan kebudayaan yang sesuai dengan kemajuan serta pembangunan semasa. Dalam masyarakat moden kini, pendidikan juga dapat menyediakan ahli masyarakat yang kental untuk menghadapi pelbagai cabaran kehidupan di samping membuat pembaharuan pembangunan serta menyelesaikan permasalahan yang berkaitan dengan masyarakat.

${ }^{c}$ Abd al Rahman al Nahlawi dalam menjelaskan beberapa keistimewaan yang terdapat dalam kurikulum pendidikan Islam menyatakan bahawa mesti ada kesejajaran antara kurikulum dengan ajaran Islam itu sendiri. Hasilnya, maka terbentuklah kurikulum yang sesuai dengan fitrah menusia, bersesuaian dengan setiap peringkat umur dan tuntutan perkembangan semasa. Kurikulum pendidikan yang mantap ini melahirkan kesan dan natijah yang baik di dalam diri individu pelajar seterusnya akan melahirkan institusi masyarakat yang cemerlang. Perlu disedari bahawa hal ini keseluruhannya bermatlamatkan pengabdian diri kepada Allah s.w.t. dan mematuhi perintahNya sebagai melaksanakan tugas khalifah di muka bumi (Nahlawi, 1979). 


\section{0 IMPLIMENTASI DIALOG PERADABAN DAN FALSAFAH PENDIDIKAN ISLAM DALAM KURIKULUM DAN} KOKURIKULUM SUBJEK UMUM FTI

Masyarakat Malaysia yang hidup berbilang kaum mempunyai latar belakang agama, berfikir, kebudayaan, adat serta cara hidup yang berbagai ragam serta berbeza. Keadaan ini pastinya akan melahirkan perspepsi, sikap dan tindakan yang berbeza antara individu atau bangsa dengan yang lain. Bahkan berkemungkinan akan sampai ke peringkat mencetuskan prejudis dan konflik antara kaum dan bangsa. Situasi ini sukar untuk dihapuskan bahkan perlu saling mengiktiraf dan akur dengan kewujudan perbezaan ini. Perspektif terbuka dan sikap lapang dada mengakui dan menghormati perbezaan selain daripada mencari persamaan dan bekerjasama dalam hal-hal yang boleh dipersetujui bersama adalah sikap fundamental yang harus wujud dalam masyarakat Malaysia. Kepentingan untuk mewujudkan masyarakat saling bantu membantu dan bekerjasama dalam hal sepakat dan sefahaman tapi saling hormat-menghormati serta akur terhadap perbezaan dan kelainan budaya dan agama.

Oleh itu pemupukan semangat untuk saling hormat menghormati dan tahap toleransi yang tinggi seharusnya diterapkan dalam sistem pendidikan bermula dari peringkat sekolah lagi. Pendidikan di sekolah berfungsi sebagai wadah yang berkesan untuk menerapkan semangat dan kefahaman sekaligus membina sifat jujur, prihatin, hormat, kerjasama, berbaik sangka, interaksi dan sikap toleran dan akur terhadap perkara yang berbeza atau yang tidak dipersetujui. Pemupukan nilai-nilai murni dan baik lebih mudah dan berkesan dilakukan semasa kanak-kanak masih kecil melalui kurikulun dan kokurikulum pendidikan yang terancang. Pemupukan nilai peringkat awal ini merupakan wadah yang berharga ke arah dialog antara peradaban. Oleh itu, bertepatan dengan perlaksanaan yang telah dilakukan oleh pihak kerajaan melalui Sekolah Wawasan sebagai suatu mikro concern kepada dialog peradaban, membolehkan murid-murid dan guruguru daripada tiga aliran dan latar belakang budaya serta agama yang sangat berlainan bertemu, berinteraksi dan berkongsi untuk kebaikan (Khir, 2005). Malah usaha pemupukan nilai ini bukan sahaja terletak di bahu mereka yang terlibat dalam sektor pendidikan semata-mata. Bahkan usaha tersebut turut melibatkan sektor-sektor lain yang perlu juga bersama-sama memainkan peranan. Sektor ekonomi dan politik misalnya sama pentingnya dengan sekolah dan universiti. Pengerak sektor-sektor ini harus menyediakan persekitaran yang selesa, seimbang dan adil untuk semua bangsa dan agama. Pengurusan dan pentadbiran harus mengikut prinsip kebenaran dan keadilan serta beretika.

Menurut Rusimah Sayuti (2004), pelajar-pelajar berbilang bangsa yang berada sama ada IPTA atau IPTS hidup dalam satu komuniti dengan tujuan yang sama iaitu menuntut ilmu lebih mudah untuk saling faham memahami dalam berbagai aspek. Sebagai contoh memahami amalan agama sesuatu bangsa terutama dalam konteks kehidupan berasrama adalah penting Dalam konteks masyarakat pelajar di institusi pengajian tinggi, pelajar adalah cerminan masyarakat Malaysia, malah mereka sebagai bakal pewaris pemimpin negara dan pemacu masyarakat maju. Jika berlaku polarisasi kaum antara pelajar, wujud konflik senyap antara pelajar dari berbagai kaum dan etnik, hubungan yang renggang antara agama dan bangsa dalam kalangan pelajar, maka sudah pasti menimbulkan persoalan, apakah akan terjadi pada generasi muda dan masyarakat Malaysia akan datang. Bagaimana corak dan warna hubungan antara kaum dan bangsa?

Salah satu pendekatan bagi menangani konflik dan polarisasi kaum dalam kalangan pelajar maka Kementerian Pendidikan Tinggi telah mewajibkan pelajar Institusi Pengajian Tinggi Awam (IPTA) maupun Swasta (IPTS) mengambil subjek Tamadun Islam dan Tamadun Asia, Kenegaraan dan Hubungan Etnik sebagai satu persiapan ke arah masyarakat yang saling hormat-menghormati antara satu sama lain melalui medium pendidikan dan dialog antara peradaban. Menyahut seruan ini Fakulti Tamadun Islam UTM terlibat secara langsung memikul tugas dan tanggungjawab ini. Selain daripada subjek umum wajib UICI 1012 TITAS, FTI turut menawarkan subjek wajib lain iaitu; UICI 2022 Sains, Teknologi dan Manusia yang perlu diambil oleh para pelajar tahun kedua melibatkan seluruh fakulti dan UHW/UICW 6023 Falsafah Sains sebagai subjek wajib yang ditawarkan kepada para pelajar di peringkat sarjana dan doktor falsafah.

Penerapan nilai dialog peradaban dan matlamat falsafah pendidikan Islam dapat diaplikasikan dalam subjek-subjek umum wajib Universiti. Strateginya pula dapat dirujuk kepada teori-teori asas dan nilai-nilai sepunya yang dibangunkan dalam kurikulum silibus subjek. Di samping itu, praktikal teorinya pula diaplikasikan dalam aktiviti-aktiviti kokurikulum yang perlu disertai oleh setiap pelajar secara individu maupun berkumpulan. Selain itu, penilaian terhadap penerapan nilai dan matlamatnya turut dapat direalisasikan menerusi kemahiran ganerik yang perlu digarap oleh para pelajar dalam aktiviti berkumpulan yang lebih bersifat prktikal. Penilaian terhadap implimentasi kemahiran tersebut dapat dirujuk dalam aktiviti-aktiviti kerja kursus dan peperiksaan akhir yang berlangsung sepanjang setiap semester. Oleh yang demikian, gambaran keseluruhannya dapat dirujuk menerusi bahan-bahan pengajaran dan pembelajaran (P\&P) yang dimuatkan sama ada dalam silibus berbentuk buku, panduan L1 dan L2, E-Learning dan MOOC's (Masive Open Online Course), khidmat masyarakat dan sebagainya dalam subjek-subjek berikut :

(a) UHW/UICW 6023 Falsafah Sains

(b) UICI 2022 Sains, Teknologi dan Manusia

(c) UICI 1012 Tamadun Islam dan Tamadun Asia

Kemahiran dialog dalam kalangan pelajar menerusi penyertaan aktiviti-aktiviti subjek umum wajib yang disediakan dapat melahirkan satu sikap ingin tahu dan belajar apa yang ada di luar lingkungan masing-masing (Sulaiman, 2004). Kesedaran ini perlu disemai dalam diri setiap pelajar yang mengambil subjek-subjek umum universiti. Berikut merupakan item penilaian yang menerapkan konsep dialog peradaban dan falsafah pendidikan Islam dalam subjek TITAS :

Jadual 1 Item penilaian kerja kursus dalam subjek Tamadun Islam dan Asia (TITAS)

\begin{tabular}{c|l|c}
\hline No. & \multicolumn{1}{|c|}{ Perkara } & Markah \\
\hline $\mathbf{1}$ & Tugasan Kumpulan & $20 \%$ \\
$\mathbf{2}$ & Pembentangan & $10 \%$ \\
$\mathbf{3}$ & Ujian / Kuiz & $20 \%$ \\
$\mathbf{4}$ & E-Learning/MOOC's /Kemahiran Generik & $10 \%$ \\
\hline & Jumlah Markah Kerja Kursus & $\mathbf{6 0 \%}$ \\
$\mathbf{4}$ & Peperiksaan Akhir & $\mathbf{4 0 \%}$ \\
\hline \multicolumn{2}{|c}{ Jumlah Markah Keseluruhan } & $\mathbf{1 0 0 \%}$ \\
\hline
\end{tabular}


Kemahiran generik yang telah diterapkan dalam pelaksanaan subjek TITAS meliputi tujuh atribut yang dicirikan oleh UTM adalah seperti berikut :

(a) Pengajian sepanjang hayat (Lifelong Learning - LL1-LL3)

(b) Kemahiran berkomunikasi (Communication Skill - CS1-CS4)

(c) Tugasan berkumpulan atau berpasukan (Teamworking - TW1-TW5)

(d) Motivasi kendiri (Self-esteem - SE1-SE4)

(e) Akhlak dan moral (Ethic - ET1-ET3)

Bersandarkan kepada konsep dialog peradaban maka aspek penting sebenarnya adalah agama. Secara langsung atau tidak langsung, dapat diperhatikan bahawa dialog yang berlaku dalam kalangan pelajar mempunyai prinsip dan elemen agama di dalamnya. Menyelusuri istilah peradaban itu sendiri membawa konotasi tentang pengisian nilai-nilai agama kerana setiap tamadun mempunyai asas yang bersandarkan kepada agama. Justeru itu, pastinya terdapat nilai yang serupa atau sepunya walaupun tidak sama, namun nilai yang serupa dapat dijadikan sebagai turning point dan titik asas untuk berinteraksi dan berkongsi pandangan dan pendapat. Maka, dalam hal ini toleransi agama dilihat sebagai teras dan aspek penting kepada pelaksanaan dialog peradaban yang perlu disemai suburkan sehingga mampu memberikan kesedaran terhadap nilai-nilai murni dan sepunya dalam kalangan pelajar yang mengambil kursus wajib subjek umum universiti.

Menerusi kandungan silibus dan kemahiran ganerik dalam aktiviti-aktiviti kerja kursus yang disediakan untuk para pelajar mampu membangunkan sikap saling memahami tentang nilai-nilai, norma-norma, pengalaman sejarah dan realiti budaya yang wujud. Oleh itu, setiap aktiviti berkumpulan perlu ada kombinasi kepelbagaian bangsa agar saling berinteraksi. Interaksi dan dialog antara ahli kumpulan berpotensi besar untuk menghindarkan konflik dalam komuniti peringkat awal dalam kalangan mahasiswa universiti. Melaluinya juga maka tertanam dalam diri pelajar nilai persefahaman, bekerjasama, berintegriti, keadilan, ketelusan, sikap saling percaya mempercayai dan sebagainya. Pendekatan tersebut bertindak sebagai asas kemahiran dan pengukuhan dalam mengimplimentasikan kaedah dialog kepada para pelajar dengan mencari langkah penyelesaian yang di persetujui bersama. Kesimpulannya, antara beberapa ciri dan kriteria yang perlu ditekuni dan dihayati oleh para pensyarah dan pelajar iaitu saling memahami terhadap nilai, norma, pengalaman sejarah dan realiti kebudayaan yang wujud. Sikap toleran terhadap pemikiran peradaban yang lain. Ini merujuk terhadap aktiviti sedia mendengar dari peradaban orang lain. Sikap lapang dada dan keterbukaan terhadap pandangan semesta orang lain dengan akomodasi dalam perspektif diri.

Berikut adalah kajian tindakan bagi melihat hasil pendapat pelajar terhadap subjek TITAS dari sedut pengajaran dan pembelajaran yang telah dilaksanakan pada semester 2 sesi 2014/2015. Batasan kajian hanya kepada para pelajar tahun 1 di Fakulti Kejuruteraan Elektrik (FKE), Fakulti Komputeran (FK), Fakulti Pengurusan (FP) dan Fakulti Bio Medic (FBME). Berikut adalah taburan responden yang telah dipecahkan kepada beberapa kumpulan. Kumpulan kelas adalah hasil gabungan beberapa seksyen:

Jadual 2 Taburan responden TITAS tahun 2014

\begin{tabular}{|c|c|c|}
\hline$B I L$ & KUMPULAN KELAS TITAS & $\begin{array}{l}\text { JUMLAH } \\
\text { PELAJAR } \\
\end{array}$ \\
\hline $\mathbf{1}$ & TITAS 1 & 140 \\
\hline 2 & TITAS 2 & 142 \\
\hline 3 & TITAS 3 & 138 \\
\hline 4 & TITAS 4 & 137 \\
\hline 5 & TITAS 5 & 141 \\
\hline & Jumlah Populasi $(N)$ & 698 \\
\hline & Jumlah Sampel Cadangan (S) - Krejcie \& Morgan (1970) & 248 \\
\hline & Jumlah Sampel yang dijalankan $(S)$ & 250 \\
\hline
\end{tabular}

Objektif kajian tindakan adalah seperti berikut :

(a) Menganalisis pendapat pelajar tentang gaya pengajaran dan pembelajaran TITAS di UTM

(b) Menganalisis dapatan markah kerja kursus kumpulan kelas TITAS

(c) Membuat analisis dapatan soal selidik gaya pengajaran dan pembelajaran TITAS dengan dapatan markah kerja kursus yang diperolehi kumpulan pelajar.

Berikut adalah dapatan soal selidik tentang gaya pengajaran dan pembelajaran pelajar dengan subjek TITAS yang dilaksanakan di UTM sepanjang semester 2 sesi 2014/2015:

Jadual 3 Dapatan soalselidik pendapat pelajar tentang gaya pengajaran dan pembelajaran TITAS di UTM 2014

\begin{tabular}{clcccccc}
\hline \multicolumn{1}{c}{ BTEMagian B : Pengajaran TITAS } & \multicolumn{1}{c}{ STS } & TS & Sd.S & S & SS & MIN \\
\hline Bil & \multicolumn{1}{c}{ ITEM } & STS & & & \\
\hline $\mathbf{1}$ & $\begin{array}{l}\text { Subjek TITAS memupuk saya berinteraksi tanpa } \\
\text { prejudis dengan bangsa lain. }\end{array}$ & 0 & 0 & 0 & 23.7 & 76.3 & $\mathbf{4 . 7 6}$ \\
$\mathbf{2}$ & $\begin{array}{l}\text { Saya sedar pemahaman dan tumpuan dalam kelas } \\
\text { amat penting. }\end{array}$ & 0 & 0 & 0 & 48.6 & 51.4 & $\mathbf{4 . 5 1}$ \\
$\mathbf{3}$ & $\begin{array}{l}\text { Pemahaman agak sukar jika pensyarah hanya } \\
\text { berkomunikasi 1 hala atau bersyarah sahaja. }\end{array}$ & 0 & 0 & 0 & 45.7 & 54.3 & $\mathbf{4 . 5 3}$ \\
$\mathbf{4}$ & $\begin{array}{l}\text { Pengajaran yang berbantukan ICT dapat } \\
\text { menjadikan pembelajaran dalam kelas lebih } \\
\text { menarik dan meningkatkan daya kefahaman. }\end{array}$ & 0 & 0 & 0 & 52.9 & 47.1 & $\mathbf{4 . 4 7}$ \\
\hline
\end{tabular}




\begin{tabular}{|c|c|c|c|c|c|c|c|}
\hline 5 & $\begin{array}{l}\text { Penggunaan bahasa yang mudah, ringkas dan } \\
\text { padat oleh pensyarah ketika mengajar } \\
\text { memudahkan tahap kefahaman. }\end{array}$ & 0 & 0 & 0 & 47.1 & 52.9 & 4.53 \\
\hline 6 & $\begin{array}{l}\text { Saya suka jika pensyarah lebih santai dalam } \\
\text { menerangkan isi pembelajaran dalam kelas. }\end{array}$ & 0 & 0 & 0 & 42.0 & 58.0 & 4.58 \\
\hline 7 & $\begin{array}{l}\text { Saya suka pengajaran menggunakan pelbagai } \\
\text { kaedah pengajaran contohnya forum, } \\
\text { perbincangan, sesi soal jawab secara santai dan } \\
\text { mudah mesra pelajar. }\end{array}$ & 0 & 0 & 0 & 76.6 & 23.4 & 4.23 \\
\hline 8 & $\begin{array}{l}\text { Saya suka pensyarah yang berketrampilan dan } \\
\text { profesional ketika mengajar dalam kelas. }\end{array}$ & 0 & 0 & 0 & 35.7 & 64.3 & 4.64 \\
\hline 9 & $\begin{array}{l}\text { Corak pengajaran pensyarah yang kurang } \\
\text { menarik akan memberi kesan tahap kefahaman } \\
\text { saya dengan subjek tersebut. }\end{array}$ & 0 & 0 & 0 & 75.4 & 24.6 & 4.25 \\
\hline 10 & $\begin{array}{l}\text { Saya suka pensyarah yang tidak garang tetapi } \\
\text { tegas perwatakannya dan sentiasa update } \\
\text { pengetahuannya dan kemahiran (ICT). }\end{array}$ & 0 & 0 & 0 & 23.7 & 76.3 & 4.76 \\
\hline \multicolumn{8}{|c|}{ Bahagian $C$ : Pembelajaran TITAS } \\
\hline Bil & ITEM & STS & TS & Sd.S & $\mathbf{S}$ & SS & MIN \\
\hline 11 & $\begin{array}{l}\text { Kepelbagaian dalam akiviti setiap sesi } \mathrm{P} \& \mathrm{P} \\
\text { menarik minat saya dalam subjek TITAS }\end{array}$ & 0 & 0 & 0 & 14.0 & 86.0 & 4.86 \\
\hline 12 & $\begin{array}{l}\text { Subjek TITAS telah membuka dimensi pemikiran } \\
\text { saya lebih luas tentang sejarah Islam }\end{array}$ & 0 & 0 & 0 & 26.9 & 73.1 & 4.73 \\
\hline 13 & $\begin{array}{l}\text { Subjek TITAS telah menjadikan diri saya tidak } \\
\text { bersikap prejudis antara agama }\end{array}$ & 0 & 0 & 0 & 63.4 & 36.6 & 4.37 \\
\hline 14 & $\begin{array}{l}\text { Saya suka dan mudah faham jika pensyarah } \\
\text { mengajar banyak menggunakan peta/ carta/ } \\
\text { gambar/ video sebagai BBM. }\end{array}$ & 0 & 0 & 0 & 72.3 & 27.7 & 4.28 \\
\hline 15 & $\begin{array}{l}\text { Saya suka bersoaljawab ketika pengajaran kerana } \\
\text { mudah dan cepat saya mengetahui sesuatu fakta } \\
\text { sejarah }\end{array}$ & 0 & 0 & 0 & 76.6 & 23.4 & 4.23 \\
\hline 16 & $\begin{array}{l}\text { Saya suka aktiviti-aktiviti yang bersifat praktikal/ } \\
\text { berkumpulan/ dalam P\&P }\end{array}$ & 0 & 0 & 6.6 & 66.3 & 27.1 & 4.21 \\
\hline 17 & $\begin{array}{l}\text { Saya suka aktiviti-aktiviti yang bersifat forum/ } \\
\text { debat dalam } \mathrm{P} \& \mathrm{P}\end{array}$ & 0 & 0 & 0.9 & 77.4 & 21.7 & 4.21 \\
\hline 18 & $\begin{array}{l}\text { Sesi pembentangan bagi setiap ahli kumpulan } \\
\text { telah membuat diri saya apabila berhadapan di } \\
\text { khalayak ramai }\end{array}$ & 0 & 0 & 2.3 & 68.3 & 29.4 & 4.27 \\
\hline 19 & $\begin{array}{l}\text { Aktiviti lakonan/ pentomen/ teater juga menarik } \\
\text { jika dimasukkan dalam aktiviti pembelajaran. }\end{array}$ & 0 & 0 & 0 & 34.9 & 65.1 & 4.65 \\
\hline 20 & $\begin{array}{l}\text { Penggunaan medium sosial network contohnya } \\
\text { facebook/ twitter/ e-learning/ blogspot dll sangat } \\
\text { membantu menarik minat dan faham terhadap } \\
\text { subjek TITAS }\end{array}$ & 0 & 0 & 0 & 71.7 & 28.3 & 4.28 \\
\hline
\end{tabular}

Berikut adalah dapatan keputusan markah kerja kursus (60\% markah) yang telah diperolehi oleh pelajar sepanjang sesi semester 2 2014/2015:

Jadual 4 Dapatan keputusan markah kerja kursus kumpulan pelajar TITAS 2014

\begin{tabular}{|c|c|c|c|c|c|c|c|}
\hline \multicolumn{8}{|c|}{ KEPUTUSAN MARKAH KERJA KURSUS KUMPULAN TITAS 1 - (60\%) } \\
\hline Bil & ITEM & $\underset{(<20)}{L}$ & $\begin{array}{c}\mathrm{S} \\
(21-30)\end{array}$ & $\begin{array}{c}\text { Sd.C } \\
(31-40)\end{array}$ & $\begin{array}{c}\mathrm{C} \\
(41-50)\end{array}$ & $\begin{array}{c}\mathrm{SC} \\
(51-60)\end{array}$ & $\begin{array}{c}\text { MIN } \\
\text { Kump. }\end{array}$ \\
\hline 1 & Tugasan Kumpulan (20\%) & 0 & 0 & 0 & 30.0 & 70.0 & 4.70 \\
\hline 2 & Pembentangan $(\mathbf{1 0} \%)$ & 0 & 0 & 0 & 30.8 & 69.2 & 4.69 \\
\hline 3 & Ujian / Kuiz (20\%) & 0 & 0 & 0 & 38.3 & 61.7 & 4.62 \\
\hline 4 & E-Learning/MOOC's /Kemahiran Generik (10\%) & 0 & 0 & 0 & 30.0 & 70.0 & 4.70 \\
\hline \multicolumn{8}{|c|}{ KEPUTUSAN MARKAH KERJA KURSUS KUMPULAN TITAS 2 - (60\%) } \\
\hline Bil & ITEM & $\begin{array}{c}\mathbf{L} \\
(<20) \\
\end{array}$ & $\begin{array}{c}\mathrm{S} \\
(21-30) \\
\end{array}$ & $\begin{array}{c}\text { Sd.C } \\
(31-40) \\
\end{array}$ & $\begin{array}{c}C \\
(41-50) \\
\end{array}$ & $\begin{array}{c}\mathrm{SC} \\
(51-60) \\
\end{array}$ & $\begin{array}{c}\text { MIN } \\
\text { Kump. }\end{array}$ \\
\hline 1 & Tugasan Kumpulan (20\%) & 0 & 0 & 0 & 45.0 & 55.0 & 4.61 \\
\hline 2 & Pembentangan (10\%) & 0 & 0 & 0 & 37.5 & 62.5 & 4.68 \\
\hline 3 & Ujian / Kuiz (20\%) & 0 & 0 & 0 & 47.5 & 52.5 & 4.59 \\
\hline 4 & E-Learning/MOOC's /Kemahiran Generik (10\%) & 0 & 0 & 0 & 30.8 & 69.2 & 4.69 \\
\hline
\end{tabular}




\begin{tabular}{|c|c|c|c|c|c|c|c|}
\hline \multicolumn{8}{|c|}{ KEPUTUSAN MARKAH KERJA KURSUS KUMPULAN TITAS 3 - (60\%) } \\
\hline Bil & ITEM & $\begin{array}{c}\mathbf{L} \\
(<\mathbf{2 0}) \\
\end{array}$ & $\begin{array}{c} \\
(21-30) \\
\end{array}$ & $\begin{array}{c}\text { Sd.C } \\
(31-40) \\
\end{array}$ & $\begin{array}{c}\mathrm{C} \\
(41-50)\end{array}$ & $\begin{array}{c}\mathrm{SC} \\
(51-60) \\
\end{array}$ & $\begin{array}{c}\text { MIN } \\
\text { Kump. }\end{array}$ \\
\hline 1 & Tugasan Kumpulan (20\%) & 0 & 0 & 0 & 56.7 & 43.3 & 4.49 \\
\hline 2 & Pembentangan $(\mathbf{1 0 \%})$ & 0 & 0 & 0 & 50.0 & 50.0 & 4.57 \\
\hline 3 & Ujian / Kuiz (20\%) & 0 & 0 & 0 & 30.8 & 69.2 & 4.69 \\
\hline 4 & E-Learning/MOOC's /Kemahiran Generik (10\%) & 0 & 0 & 0 & 28.3 & 71.7 & 4.72 \\
\hline \multicolumn{8}{|c|}{ KEPUTUSAN MARKAH KERJA KURSUS KUMPULAN TITAS 4 - (60\%) } \\
\hline Bil & ITEM & $\begin{array}{c}\mathbf{L} \\
(<20) \\
\end{array}$ & $\begin{array}{c}S \\
(21-30) \\
\end{array}$ & $\begin{array}{c}\text { Sd.C } \\
(31-40)\end{array}$ & $\begin{array}{c}\mathrm{C} \\
(41-50)\end{array}$ & $\begin{array}{c}\mathrm{SC} \\
(51-60) \\
\end{array}$ & $\begin{array}{r}\text { MIN } \\
\text { Kump. }\end{array}$ \\
\hline $\mathbf{1}$ & Tugasan Kumpulan (20\%) & 0 & 0 & 0 & 45.8 & 54.2 & 4.54 \\
\hline 2 & Pembentangan $(\mathbf{1 0 \%})$ & 0 & 0 & 0 & 28.3 & 71.7 & 4.72 \\
\hline 3 & Ujian / Kuiz (20\%) & 0 & 0 & 0 & 41.7 & 58.3 & 4.58 \\
\hline 4 & E-Learning/MOOC's /Kemahiran Generik (10\%) & 0 & 0 & 0 & 37.5 & 62.5 & 4.68 \\
\hline \multicolumn{8}{|c|}{ KEPUTUSAN MARKAH KERJA KURSUS KUMPULAN TITAS 5 - (60\%) } \\
\hline Bil & ITEM & $\begin{array}{c}\mathbf{L} \\
(<20) \\
\end{array}$ & $\begin{array}{c} \\
(21-30) \\
\end{array}$ & $\begin{array}{c}\text { Sd.C } \\
(31-40) \\
\end{array}$ & $\begin{array}{c}\mathrm{C} \\
(41-50)\end{array}$ & $\begin{array}{c}\mathrm{SC} \\
(51-60) \\
\end{array}$ & $\begin{array}{c}\text { MIN } \\
\text { Kump. }\end{array}$ \\
\hline $\mathbf{1}$ & Tugasan Kumpulan (20\%) & 0 & 0 & 0 & 30.8 & 69.2 & 4.69 \\
\hline 2 & Pembentangan (10\%) & 0 & 0 & 0 & 50.0 & 50.0 & 4.57 \\
\hline 3 & Ujian / Kuiz (20\%) & 0 & 0 & 0 & 44.2 & 55.8 & 4.56 \\
\hline 4 & E-Learning/MOOC's /Kemahiran Generik (10\%) & 0 & 0 & 0 & 37.5 & 62.5 & 4.68 \\
\hline
\end{tabular}

Petunjuk : SC - Sangat cemerlang ; C - Cemerlang ; Sd.C - Sederhana cemerlang ; S - Sederhana ; L - Lemah

$* N=250$

Berdasarkan dapatan soal selidik dan keputusan markah kerja kursus bagi setiap kumpulan TITAS 1 hingga kumpulan TITAS 5 dapat disimpulkan trend dapatan nilai min (purata) dapatan tidak jauh nilai perbezaannya. kedua-dua dapatan berada dalam kelompok nilai min (purata) kumpulan $(>4.00)$ dan membawa maksud nilai tersebut adalah sangat tinggi atau sangat positif. Tiada dapatan soal selidik pendapat pelajar yang mendapat nilai min (purata) <4.00. Justeru hasil dapatan bagi kedua-dua instrumen tersebut tiada perbezaan yang terlalu jauh. Ini juga menggambarkan ada keselarasan kemahiran generik yang telah diobjektifkan di peringkat permulaan dengan hasil keputusan kerja kursus pelajar sebanyak $60 \%$ pemarkahannya.

Segala usaha yang dilaksanakan perlu diteruskan bagi mempertingkatkan kesedaran dalam diri pelajar sebaliknya menyingkirkan kekeliruan dan salahfaham terhadap matlamat yang diharapkan menerusi usaha murni tersebut. Jelas bahawa elemen dialog peradaban amat perlu dalam konteks pelajar yang pelbagai bangsa seterusnya peringkat masyarakat majmuk atau pelbagai tamadun. Namun kefahaman yang benar dalam kalangan peserta dialog dan mereka yang serius dalam dialog sama ada melibatkan pihak pensyarah mahupun pelajar perlu mendalami konsep, tujuan, kaedah berdialog dan prasarana dialog.

Jelasnya, dialog peradaban dapat menghalang daripada terjadinya konflik di peringkat antarabangsa, nasional dan tempatan melalui pengurangan kesalahfahaman dan ketidakpercayaan. Menerusi pendekatan ini dapat diperjelaskan tentang kekeliruan dan salah faham terhadap Islam seperti Islamaphobia, Islamic bombist, terrorisme, extreemisme, fanatisme dan lainnya sebagai suatu tuduhan liar mampu di atasi sebaiknya. Ia juga mempunyai potensi yang sangat besar bagi menyelesaikan masalah-masalah berkaitan ekonomi semasa dan masa depan, sosial dan politik melalui perkongsian pengalaman seterusnya dapat mencari penawar kepada pelaksanaannya. Kesedaran di peringkat awal dalam kalangan pelajar universiti perlu diutamakan kerana mereka sebagai cerminan terhadap kefahaman dan kesedaran masyarakat umum. Walau bagaimana pun terdapat segelintir pelajar yang sukar menerima landasan subjek umum sebagai suatu langkah bijak kerajaan (KPM) mengurangi jurang kekeliruan, ketidakpercayaan, dan salahfaham yang berlaku. Namun hakikat yang disedari bahawa kebanyakan pelajar yang bersikap demikian lebih kepada mereka yang berlatarbelakang pendidikan di sekolah bukan integrasi atau tidak bersepadu. Hal ini perlu kepada penambahbaikan kurikulum dan kokurikulum dalam subjek umum universiti begitu juga pedagogi oleh pensyarah yang terlibat.

\subsection{KESIMPULAN}

Dialog peradaban berperanan penting ke arah mewujudkan masyarakat yang aman dan harmonis, hidup damai dalam kepelbagaian ragam namun masih dapat memelihara prinsip dan nilai peradaban masing-masing. Bagi memastikan kehidupan masyarakat terus mengecapi keamanan dan keharmonian maka nilai-nilai persefahaman, toleransi, hormat menghormati dan kerjasama antara satu sama lain harus terus dipupuk oleh semua peringkat lapisan masyarakat dan organisasi. Manusia dari pelbagai anutan agama dan kepercayaan mampu membina hidup yang sempurna apabila mereka bersatu dalam persamaan dan menghormati perbezaan masing-masing. Kesedaran tentang nilai-nilai murni tersebut perlu disemai dan disuburkan dalam diri masyarakat dan pendidikan sebagai suatu wahana yang amat penting untuk merealisasikan matlamat tersebut. Peranan sektor pendidikan sangat berkait rapat dengan kehidupan sesebuah masyarakat ke arah mencapai matlamat kecemerlangan. Kepentingan dan peranan pendidikan sangat diperhatikan oleh Islam. Justeru, kefahaman yang dikehendaki dalam falsafah pendidikan Islam adalah suatu pemikiran mendalam, sitematik, logik dan menyeluruh yang terbentuk atau tersusun ke dalam suatu bentuk pemikiran atau konsepsi sebagai suatu sistem.

Apabila dikaitkan dengan Islam, maka jelaslah falsafah tersebut merupakan penghasilan (menifestasi) dari pelbagai sumber daya fikiran, perasaan dan kemahuan berdasarkan ajaran Islam yang dinyatakan oleh ahli falsafah yang bernafaskan Islam di sepanjang masa dan tempat. Ruang lingkup pemikirannya juga tidak terbatas dalam lingkungan institusi Islam sahaja atau ilmu pengetahuan dan pengalaman keislaman semata-mata, bahkan menjangkau segala ilmu dan pengalaman yang luas seluas aspirasi masyarakat Muslim. 
Menyedari hakikat sistem pendidikan asing gagal menyediakan pendidikan sewajarnya kepada individu dan masyarakat seperti yang dituntut oleh Islam, maka sudah sampai masanya umat Islam kembali kepada kitab suci al-Quran dan Sunnah RasululLah s.a.w sebagai sumber utama bagi melahirkan teori-teori pendidikan Islam. Di samping itu juga, segala fenomen-fenomena utama yang menjulang kecemerlangan dan kegemilangan ilmu dalam sejarah dan tamadun Islam generasi awal, perlu dihayati dan dijadikan asas panduan dalam usaha mengembalikan kecemerlangan umat Islam, terutamanya ketika menghadapi cabaran dunia tanpa sempadan. Sejarah yang gemilang tidak hanya bersifat nostalgik semata-mata tetapi perlu diulangi pada masa kini dan akan datang.

Menyelusuri Konsep 1 Malaysia yang dapat dihubungkan dengan peranan dialog peradaban bahawa peranannya sebagai membawa aspirasi untuk memperkukuhkan hubungan kaum. Ia bertujuan bagi memastikan rakyat Malaysia dapat menjalin perpaduan yang lebih erat sebagaimana kehendak prinsip Rukun Negara. Perkara yang perlu diwujudkan dalam semangat perpaduan adalah perasaan hormat menghormati dan sikap saling mempercayai antara kaum. Rakyat perlu memahami dan mengamalkan bahawa segala tindakan perlu mengutamakan kepentingan negara. Pembinaan negara bangsa bagi sebuah negara berbilang kaum seperti Malaysia amat penting terutama dalam era globalisasi yang membenarkan pengaliran secara bebas dan pantas bukan sahaja maklumat, modal serta manusia tetapi juga sistem nilai, budaya dan kepercayaan dari pelbagai negara. Keupayaan membina negara bangsa amat bergantung kepada perkongsian nilai integriti, kebolehan, dedikasi dan kesetiaan. Sesungguhnya semua rakyat Malaysia perlu mendasari prinsip-prinsip kebersamaan (togetherness) dan kekitaan (sense of belonging). Bagi menjayakan konsep ini maka peranan pendidikan berkesan sangat diperlukan.

Menerusi pendidikan mampu memberi kesedaran supaya setiap kaum perlu mengikis habis sifat asabiyyah kaumiyyah dan menggantikannya dengan nilai yang universal. Dalam hal ini Islam perlu dirujuk terhadap nilai-nilai 1Malaysia dan prinsip ini telah diperakukan dalam Perlembagaan Malaysia yang memperuntukkan Islam sebagai agama persekutuan. Kita mengharapkan konsep 1Malaysia ini benar-benar terlaksana dan tidak bersifat retorik politik demi mempertahankan survival golongan tertentu dalam negara.

\section{Rujukan}

Abbud, A.A. G. (1990). al Tarbiyyah al Islamiyyah wa al Tahaddiyat al Asr. al Qaherah, Dar al fikr al Arabi.

Ahmad, K. (1979). Prinsip-prinsip Pendidikan. Bumiprint, Kuala Lumpur.

Arifin, H. M. (1991). Filsafat Pendidikan Islam. Edisi-2.. Bumi Aksara, Jakarta

Basri, G. (1990). Christian Mission and Islamic Da'wah in Malaysia. Angkatan Belia Islam Malaysia, Kuala Lumpur.

Brubacher, J. S. (1969). Modern Philosophies of Education. Edisi-4. Graw-Hill Company, New York Mc.

Daia, M. (1974). Prinsip Am Pendidikan. Pustaka Aman Press, Kelantan.

Daradjat, Z. (1992). Ilmu Pendidikan Islam. Edisi-2. Bumi Aksara, Jakarta.

Dewey, J. (1966). Democracy and Education. The Free Press, New York.

Fadil, S. (2003). Perspektif Qur'ani: Siri Wacana Tematik. Tradisi Ilmu Sdn. Bhd, Kuala Lumpur.

Farhan, I. A. (1979). Nahw Siyaghah al Islamiyyah li Manahij al Tarbiyyah wa al Ta'lim. al Nadwah al Islāmiyyah, Jordan.

Ghazali, A. H. M. b. M. a. (1939). Ihya' Ulum al din. Matba'ah Mustafa al Baby al Halaby, Misr.

Horne, H. H. (1962 ). An Idealistic Philosophy of Education. The Forty First, Yearbook of The National Society for The Study of Eduacation. Philosophies of Eduacatio. E1. The Univercity of Chicago Press, Chicago.

Ishak, A. A. (1995). Pendidikan Islam dan Pengaruhnya di Malaysia. Dewan Bahasa dan Pustaka, Kuala Lumpur.

Ishak, A. A. B. (1989). Sejarah Perkembangan Pelajaran dan Pendidikan Islam. Jiwamas Printers Sdn. Bhd, Selangor.

Iskandar, T. (2000). Kamus Dewan. Edisi-3. Dewan Bahasa dan Pustaka, Kuala Lumpur.

Jamali, M. F. A. (1972). Nahw al Tauhid al Fikr al Tarbawi fi al A'lam al Islami. Dar al Tunisiyyah, Tunisia.

Kamus Dewan (2005). Dewan Bahasa dan Pustaka, Kuala Lumpur.

Kasa, A. A. R. A. D. Z. (1994). Falsafah dan Konsep Pendidikan. Edisi-2. Fajar Bakti Sdn. Bhd, Kuala Lumpur.

Khir, M. M. (2005). Sekolah Wawasan Sebagai Asas Dialog Peradaban dalam Seminar Kebangsaan Dialog Peradaban: Peranan dan Kepentingannya Di Malaysia Institut Perkembangan Minda ( INMIND), Petaling Jaya.

Kilpatrick, H. W. (1961). Philosophy of Education. Macmillan Company, New York.

Langgulung, H. (1979). Pendidikan Islan Suatu Analisa Sosio-psikologikal. Pustaka Antara, Kuala Lumpur.

Langgulung, H. (1986). Pengenalan Tamadun Islam dalam Pendidikan. Dewan Bahasa dan Pustaka, Selangor.

Ibn Manzur, A. A. F. M. M. I. (1955-1956). Lisan al Arab. Dar Sadir, Beirūt.

Mohammad Hamid al Efendi, T. t. N. M. I., Nahwu Manahij Islamiyyah, Majallah Kuliah al Tarbiyyah. Jāmicah al Riyadh, Riyadh.

Muhammady, A. A. H. E. (1991). Pendidikan Islam: Falsafah, disiplin dan Peranan Pendidik. Dewan Pustaka Islam, Selangor.

Muzaffar, C. (2003). Muslim, Dialogue, Terror. JUST, Petaling Jaya.

Nahlawi, A. a. R. a. (1979). Usul al Tarbiyyah al Islamiyyah wa Asalibuha fi al Bait wa al Madrasah wa al Mujtamak. Dār al Fikr, Dimas.

Nocholls, A. (1972). Developing a Curriculum a Practical Guide. George Allen and Unwin (Publishers) Ltd, London.

Raziq, M. A. (1959). Tamhid li Tarikh al Falsafah al Islamiyyah. Lujnah al Ta'lif wa al Tarjamah wa al Nasyr, al Qaherah.

Sadiq, S. A. (1962). al Falsafah wa al Tarbiyyah. Dar Fikr, Qāherah.

Sayuti, R. (2004). Kajian Hubungan Kaum di Kalangan Pelajar Sekolah Pembangunan Sosial, Universiti Utara Malaysia. Paper presented at the Seminar Antarabangsa Pemantapan Nilai dalam Komuniti Pasca Modenisme, Langkawi Kedah.

Shaibani, U. M. A. (1975). Falsafah al Tarbiyyah al Islamiah. T.tp, Tripoli.

Shipley, J. T. (1957). Dictionary of World Origins. Ames Lowa, USA.

Sulaiman, S. T. (2004). Dialog Peradaban Agama di Malaysia; Praktik dan Kerelevenannya Hari Ini. Dalam Pemikir. Utusan Karya Sdn. Bhd, Kuala Lumpur.

Zuhairini. (1992). Filsafat Pendidikan Islam. Bumi Aksara, Jakarta. 